\title{
In Vitro and in Vivo Cytotoxic Effects of Chlorella Against Various types of Cancer
}

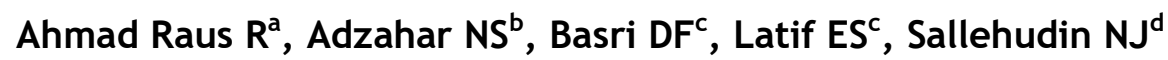 \\ ${ }^{a}$ Faculty of Engineering, International Islamic University Malaysia, 53100 Gombak, Kuala Lumpur \\ ${ }^{b}$ Faculty of Industrial Sciences \& Technology, Universiti Malaysia Pahang, 26300 Gambang, Pahang \\ ${ }^{\mathrm{c}}$ Faculty Health Sciences, Universiti Kebangsaan Malaysia, Jalan Raja Muda Abdul Aziz, 50300 Kuala Lumpur \\ ${ }^{\mathrm{d}}$ Forest Research Institute Malaysia, 68100 Kepong, Selangor
}

\section{ABSTRACT}

Chlorella is one of the microalgae that had been studied intensively owing to its rapid growth and easily cultured at a large scale compared to other microalgae and valuable nutrient compositions. Numerous studies have observed that Chlorella possess various health benefit including antioxidant, anti-cholesterol, anti-inflammatory, and antiproliferative effect against many types of cancer. In this review paper, the effects of various Chlorella species against cancer cells and animal induced cancer are discussed and an overview on Chlorella is briefed. The Chlorella deleterious effect on cancer through various mechanisms such as enhancement of immune system and apoptosis; improving lipid peroxidation; synthesis and expression of the protein-degrading matrix; and preventing the formation of new blood vessels are elaborated as well. Based on the findings of many studies reported in this article, it can be suggested that Chlorella has the potential in supporting cancer therapy and may develop to become an anti-cancer agent.

KEYWORDS: Chlorella, cancer, anti-proliferative, mechanism

\section{INTRODUCTION}

Cancer is the leading cause of death in the world with an estimated 18.1 million new cancer cases and 9.6 million cancer deaths in 2018 despite existence. ${ }^{1}$ There has been a steadfast rise in cancer incidence and mortality globally every year due to an increase in population and age. According to the report of the International Agency for Research on $\mathrm{Cancer}^{2}$, nearly half of the diagnosed cancer cases and more than half of the cancer deaths worldwide occur in Asia partly due to $60 \%$ of the global population comes from this region. Europe and the Americas recorded $23.4 \%$ and $21.0 \%$ of the global cancer cases, respectively, and $20.3 \%$ and $14.4 \%$ of the cancer death, respectively.

\section{Corresponding Author:}

Assoc. Prof. Dr. Raha Ahmad Raus

Faculty of Engineering, International Islamic University Malaysia,

P.O. Box 10, 50728, Kuala Lumpur, Malaysia.

Tel No : +03-61964588

E-mail : rahaar@iium.edu.my
Currently, cancer is treated by surgery, radiation therapy, and chemotherapy in which surgery involves tumour removal; radiation therapy includes exposure of the tumour to radiation and chemotherapy involves drug administration into the patient's body. ${ }^{3}$ Often, radiation therapy, and chemotherapy are used alone or in combination, before or after surgery to destroy tumour remnants and reduce the cancer recurrence. However, chemotherapy proved to be the most effective treatment as the drug travels throughout the entire body to kill any cancer cells. Unfortunately, both chemotherapy and radiotherapy always comes with toxicity either to normal cells neighbouring the cancer bulk $k^{4}$ or the distance sites in various organs and cause hepatotoxicity, cutaneous toxicity, cardiotoxicity, and abnormal bone and mineral metabolism. ${ }^{5}$ High-dose chemotherapy often led to ROS-induced cytotoxicity and kills normal cells. Thus, a combination of chemotherapy with antioxidants may improve chemotherapy treatment. One study showed the extract of microalgae particularly Chlorella extract not only has 
an anti-cancer effect against hepatocellular cancer cell line (HepG2) and Ehrlich ascites carcinoma cell, it also exhibits antioxidant activity. ${ }^{6}$ Administration of Chlorella glycoprotein was also observed to reduce the side effect of 5-fluorouracil (5 FU), a chemotherapy drug that causes myelosuppression by accelerating the recovery of hematopoietic stem cells. ${ }^{7}$ It was found the Chlorella glycoprotein exerted this positive effect without affecting the antitumor activity of the drug. These attributes made Chlorella attractive to be used in combination or adjuvant with standard chemotherapy in various cancer types and have the potential to be used as an anti-cancer agent. In the following subtopics, investigations on Chlorella effects against various types of cancer-based on were elaborated and the overall background of Chlorella was explained.

\section{Chlorella}

Chlorella is a eukaryotic microalga that falls under Chlorophyta or known as the green algae group. It is one of the most important genera under the group, as it portrays many biological compounds that have medical importance. It is spherical to ovoid (Figure 1) with a microscopic size of $2-10 \mu \mathrm{m}$ diameters and lack of flagella (non-motile).

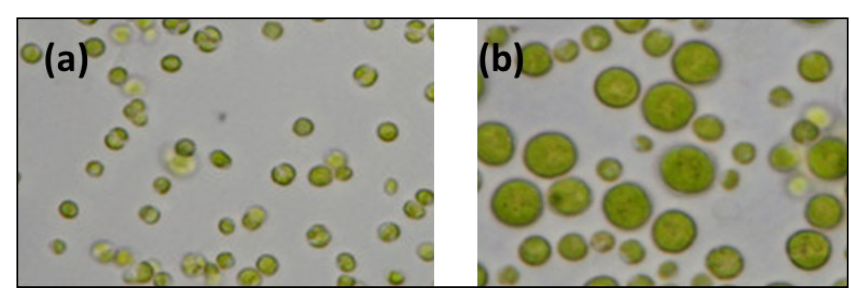

Figure 1: (a) Chlorella sorokiniana (b) Chlorella zofingiensis ${ }^{8}$

The primary composition of Chlorella is proteins (51\%$58 \%$ ), lipids (14\%-22\%), and carbohydrates (12\%-17\%); and other elements in Chlorella include vitamins, minerals, and pigments. Proteins in Chlorella have various functions with almost $20 \%$ of them bound to the cell wall, more than $50 \%$ are in the cytoplasm and $30 \%$ migrate in and out of the cell. ${ }^{9}$

Chlorella can synthesize essential and non-essential amino acids and because of this, they are used in human and animal nutrition. ${ }^{10}$ In Chlorella, there are two main types of lipids which are polar lipids (glycolipids and phospholipids) and nonpolar lipids or neutral lipids (mono-, di-, and triacylglycerols) as well as small amounts of free fatty acids. ${ }^{11}$ While carbohydrates in Chlorella are mainly starch which can be found in the chloroplast, another is cellulose that made the cell wall. ${ }^{12}$ In the cell wall of Chlorella, a mix of sugars such as rhamnose, galactose, glucose, xylose, arabinose, and mannose can also be found. ${ }^{13}$ In Chlorella vulgaris, important vitamins such as Vitamin A, E, C, and B complex were detected. Macro- and microminerals are found also in Chlorella ${ }^{14}$ with potassium, sodium and phosphorus are higher than other minerals. Chlorophyll is the most abundant pigment in Chlorella as it functions to absorb light for photosynthesis. ${ }^{15}$ Also, Chlorella also possesses accessory pigments for a similar function and they include various carotenoids (Table I) that have numerous health potential benefits.

Table I: Pigment content in C. vulgaris ${ }^{15}$

\begin{tabular}{ll}
\hline Pigments & $\begin{array}{l}\text { Dry Weight } \\
\left(\boldsymbol{\mu g} \mathbf{g}^{-1}\right)\end{array}$ \\
\hline B-Carotene & $7-12,000$ \\
Astaxanthin & 550,000 \\
Canthaxanthin & 362,200 \\
Lutein & $52-3830$ \\
Chlorophyll-a & $250-9630$ \\
Chlorophyll-b & $72-5770$ \\
Pheophytin-a & $2310-5640$ \\
Pheophytin-b & N/A \\
Violaxanthin & $10-37$ \\
\hline
\end{tabular}

Due to its nutritional composition, water extract of Chlorella is made into "Chlorella Growth Factor" as the Chlorella water extract contains various components such as nucleic acids, amino acids, vitamins, minerals, polysaccharides, glycoproteins, etc. ${ }^{16}$ Because Chlorella also contains carotenoids such as $\alpha$ - and $\beta$-carotenes, lutein, zeaxanthin, violaxanthin, neoxanthin. canthaxanthin and astaxanthin, several species of Chlorella have been proposed and extensively studied to be a producer for lutein and astaxanthin. ${ }^{17,18}$

Both lutein and astaxanthin has been known for its antioxidant property and may contribute in prevention of many diseases including cardiovascular, inflammatory, and cancer diseases. Intake of Chlorella itself and its extract has been shown to enhance immune functions ${ }^{19}$, reduce cholesterol and hypertension 20,21 , improve 
ulcerative colitis 22 , and prevent from tumour and cancer diseases $^{23}$.

\section{Effect of Chlorella on Cancer}

Numerous studies have shown that microalgae found in both fresh and sea waters contain compounds that are potent to several types of cancer. ${ }^{24}$ Out of all microalgae, a growing number of studies investigated Chlorella for its potential to treat cancer as compared to other eukaryotic microalgae owing to its various nutritional composition, rapid growth, and resilience in suspension culture. In this article, 68 experimental or original articles are reviewed but only 22 of the most significant observations on Chlorella effects against cancers are discussed here. The types of Chlorella extract and the methodology of treatment adopted in the 22 articles are shown in Table II.

\section{Breast Cancer}

Early investigation on the effect of Chlorella against breast cancer was carried out by administrating heat extracted of Chlorella pyrenoidosa orally and intraperitoneally before mice were transplanted with mouse mammary carcinoma cells (MM-2). ${ }^{25}$ This investigation demonstrated that up to $80 \%$ of the mice survived more than 60 days compared to control (tumour bearing mice) that died within 20 days. Another study showed C. vulgaris-treated tumour bearing mice were alive up to 45 days while the control died within 20 days when the $C$. vulgaris was given after the cancer treatment. ${ }^{26}$ In this study, myelosuppression observed in tumour bearing mice indicated by decreased numbers of bone marrow and spleen granulocyte-macrophage progenitor cells (CFU-GM) was restored after administration of Chlorella. This suggests that the anticancer effect of Chlorella extract may at least in part, attribute to the enhancement of the extract to produce and maturate granulocytes and macrophages. A more recent study demonstrated that the restoration of the reduced number of CFU-GM cells in Ehrlich bearing mice by $C$. vulgaris cell fed is because the extract increased the production of IL- 6 and IL- $1 \alpha .{ }^{27}$ Also, the C. vulgaris fed enhanced natural killer cell activity and production of IL-2, IFN- $\gamma$, and TNF- $\alpha$ that were reduced in the tumour bearing mice. These could have led to the anti-breast cancer effect of the Chlorella extract. 27

Another study showed providing C. pyrenoidosa powder to the diet of breast cancer-induced rats (by treating with $\mathrm{N}$-methyl-N-nitrosourea) suppressed tumour frequency up to $61 \%$ and lengthened tumour latency up to 12.5 days compared to non-treated rats. ${ }^{28}$ This suppressed tumour activity may be explained due to the elevated expression of apoptosis executioner protein, caspase-7, and reduced expression of vascular endothelial growth factor receptor-2 (VEGFR2) which is responsible for degrading matrix components for migration and proliferation of cells after Chlorella diet treatment was given. ${ }^{28}$ The inhibitory effect of Chlorella against breast cancer could also because of the inhibition of MMP-1 at mRNA and protein levels through c-Jun down-regulation. ${ }^{29}$ MMP-1 which is responsible for degrading matrix components for migration and proliferation of cells was found to be over-expressed in breast cancer. ${ }^{30}$ Similarly to c-Jun which was also over-expressed in breast cancer. ${ }^{31}$ Thus, downregulation of both MMP-1 and c-Jun by Chlorella could have led to the negative effect against breast cancer.

In the most recent study, the capability of Chlorella to generate oxygen via photosynthesis was used to treat a hypoxic tumour in mice. C. vulgaris was incorporated in BSA-gel which contains ultrasmall gold nanorods (AuNRs). ${ }^{32}$ This Chlorella-gold gel complex was later transplanted within the xenografted $4 \mathrm{~T} 1$ breast tumors and improved the hypoxic state of the tumour after exposure to $660-\mathrm{nm}$ light. The presence of oxygen via an increase in oxy-hemoglobin level in hypoxic tumors of mice improved the effect of doxorubicin (dox) to kill the tumour compared to dox-treated mice without the Chlorella-gold gel complex. While the presence of gold nanorods in the gel complexes increases the temperature of immediate vicinity upon $800-\mathrm{nm}$ light and led to the expansion of tumour vasculature which enhances the delivery of dox to kill cancer.

\section{Liver cancer}

Chlorella has been reported to exert negative effects against liver cancer. It was observed in a study carried 
Table II: The types of Chlorella forms and; in vitro and in vivo methodology of Chlorella treatment

\begin{tabular}{|c|c|c|c|c|}
\hline $\begin{array}{l}\text { Types of } \\
\text { Cancer }\end{array}$ & Chlorella species & Types of Chlorella & Treatment Method & References \\
\hline \multirow[t]{6}{*}{ Breast } & Chlorella pyrenoidosa & $\begin{array}{l}\text { - Non-treated Chlorella } \\
\text { - Autoclaved Chlorella } \\
\text { - Hot water extracts of Chlorella } \\
\text { (Chlorella extract by hot water) } \\
\text { - Cell wall fraction of Chlorella }\end{array}$ & $\begin{array}{l}\text { Oral and intraperitoneal treatments of } \\
\text { extract at } 1 \mathrm{mg} / \text { animal of different types } \\
\text { of Chlorella were administered to the } \\
\text { respected group of mice before mouse } \\
\text { mammary carcinoma cells (MM-2) were } \\
\text { transplanted to the mice. } \\
\text { Treatment for every other day from } 7 \text { to } \\
2 \text { days before the tumor transplantation. }\end{array}$ & 25 \\
\hline & C. vulgaris & $\begin{array}{l}\text { Dry C. vulgaris (CVE) obtained } \\
\text { from Chlorella Industry Co Ltd } \\
\text { (Tokyo, Japan) was dissolved in } \\
\text { distilled water }\end{array}$ & $\begin{array}{l}\text { Oral administration of } 50,100 \text {, or } 200 \\
\mathrm{mg} / \mathrm{kg} \text { CVE to Ehrlich ascites tumor- } \\
\text { bearing mice for } 5 \text { consecutive days. }\end{array}$ & 26 \\
\hline & C. vulgaris & $\begin{array}{l}\text { Dry C. vulgaris provided by } \\
\text { Chlorella Industry Co Ltd } \\
\text { (Fukuoka, Japan) was dissolved in } \\
\text { distilled water }\end{array}$ & $\begin{array}{l}\text { Daily oral treatment of } 50 \mathrm{mg} / \mathrm{kg} \\
\text { Chlorella to Ehrlich ascites tumor- } \\
\text { bearing mice starting } 10 \text { days before } \\
\text { tumor inoculation and being extended } \\
\text { for periods of } 3,8 \text {, or } 13 \text { days after } \\
\text { tumor inoculation. }\end{array}$ & 27 \\
\hline & C. pyrenoidosa & C. pyrenoidosa powder & $\begin{array}{l}\text { Chlorella powder was mixed with diet at } \\
\text { concentrations of } 0.3 \% \text { and } 3 \% \text { and fed } \\
\text { to mice one week before carcinogen }(\mathrm{N} \text { - } \\
\text { methyl-N-nitrosourea) administration } \\
\text { and until } 14 \text { week after carcinogen } \\
\text { administration. }\end{array}$ & 28 \\
\hline & C. minutissima & $\begin{array}{l}\text { Protein extract of C. minutissima } \\
\text { (extract obtain after hot alkali } \\
\text { treatment to cell pellet) }\end{array}$ & $\begin{array}{l}\text { Protein extract of } C \text {. minutissima at } 10-25 \\
\mu \mathrm{g} / 100 \mu \mathrm{l} \text { were treated to MDA-MB } \\
231 \text { and HepG } 2 \text { cells for } 24 \mathrm{hrs} \text {. }\end{array}$ & 29 \\
\hline & C. vulgaris & $\begin{array}{l}\text { Gelling BSA-PEG-based hydrogel } \\
\text { containing Chlorella and gold } \\
\text { nanorods (Chlorella } \\
\text { AuNRs BSA-Gel) }\end{array}$ & $\begin{array}{l}\text { Injection of Chlorella } \\
\text { AuNRs BSA-Gel near to the tumor site } \\
\text { in mice until the } 20^{\text {th }} \text { day. The mice } \\
\text { were xenografted with } 4 \text { T1 breast } \\
\text { cancer cells. }\end{array}$ & 32 \\
\hline \multirow[t]{8}{*}{ Liver } & C. vulgaris & C. vulgaris pellet & $\begin{array}{l}\text { Daily force-feeding of C. vulgaris pellet at } \\
50,150 \text {, and } 300 \mathrm{mg} / \mathrm{kg} \text { body weight to } \\
\text { liver cancer-induced rats for } 12 \text { weeks. }\end{array}$ & 33 \\
\hline & C. vulgaris & C. vulgaris pellet & $\begin{array}{l}\text { Daily force-feeding of C. vulgaris pellet } \\
\text { at } 50,150 \text {, and } 300 \mathrm{mg} / \mathrm{kg} \text { body weight } \\
\text { to liver cancer-induced rats for } 12 \\
\text { weeks. }\end{array}$ & 35 \\
\hline & & C. vulgaris hot water extract & $\begin{array}{l}\text { C. vulgaris water extract at } 0.1-4 \mathrm{mg} / \mathrm{ml} \\
\text { was treated to HepG2 cells for } 24 \mathrm{hrs} \text {. }\end{array}$ & \\
\hline & C. vulgaris & C. vulgaris water extract & $\begin{array}{l}\text { C. vulgaris water extract at } 0.1-4 \mathrm{mg} / \mathrm{ml} \\
\text { was treated to HepG2 cells for } 24 \mathrm{hrs} \text {. }\end{array}$ & 36 \\
\hline & C. vulgaris & C. vulgaris pellet & $\begin{array}{l}\text { Daily force-feeding of C. vulgaris pellet } \\
\text { at } 50,150 \text {, and } 300 \mathrm{mg} / \mathrm{kg} \text { body weight } \\
\text { to liver cancer-induced rats for } 12 \\
\text { weeks. }\end{array}$ & 37 \\
\hline & C. vulgaris & $\begin{array}{l}\text { Hot water extract of C. vulgaris } \\
\text { which was isolated in Malaysia and } \\
\text { Japan }\end{array}$ & $\begin{array}{l}\text { C. vulgaris water extract at } 0.1-4 \mathrm{mg} / \mathrm{ml} \\
\text { was treated to HepG2 cells for } 24 \mathrm{hrs} \text {. }\end{array}$ & 38 \\
\hline & C. vulgaris & $\begin{array}{l}\text { C. vulgaris (purchased at Puli, } \\
\text { Nantou, Taiwan) aqueous extract }\end{array}$ & $\begin{array}{l}\text { C. vulgaris aqueous extract at total } \\
\text { phenolic content } 30-90 \mu \mathrm{g} \text { was treated } \\
\text { to HepG } 2 \text { cells for } 72 \text { hrs. }\end{array}$ & 39 \\
\hline & C. minutissima & $\begin{array}{l}\text { Protein extract of C. minutissima } \\
\text { (extract obtain after hot alkali } \\
\text { treatment to cell pellet) }\end{array}$ & $\begin{array}{l}\text { Protein extract of } C \text {. minutissima at } 10-25 \\
\mu \mathrm{g} / 100 \mu \mathrm{l} \text { were treated to MDA-MB } \\
231 \text { and HepG } 2 \text { cells for } 24 \text { hrs. }\end{array}$ & 29 \\
\hline \multirow[t]{4}{*}{ Colorectal } & $\begin{array}{l}\text { C. vulgaris } \\
\text { C. ellipsoidea }\end{array}$ & $\begin{array}{l}\text { - Semipurified extracts of } C \text {. vulgaris } \\
\text { containing mostly carotenoids } \\
\text { - Semipurified extracts of } C \text {. ellipsoidea } \\
\text { containing mostly carotenoids }\end{array}$ & $\begin{array}{l}\text { Semipurified extracts of C. vulgaris and } \\
\text { C. ellipsoidea at } 5-100 \mu \mathrm{g} / \mathrm{ml} \text { were } \\
\text { treated to HCT116 cells for } 24 \mathrm{hrs} \text {. }\end{array}$ & 40 \\
\hline & C. protothecoides & $\begin{array}{l}\text { - C. protothecoides oil extract } \\
\text { encapsulated within polymer micro } \\
\text {-particles } \\
\text { - non-encapsulated C. protothecoides } \\
\text { oil }\end{array}$ & $\begin{array}{l}\text { Human glioblastoma cells (A172), and } \\
\text { human colorectal cancer cells (HCT- } \\
\text { 116) were treated with } 17.5,35 \text {, and } 70 \\
\mu \mathrm{M} \text { chlorella oil microparticles and non- } \\
\text { encapsulated } C \text {. protothecoides oil for } 48 \\
\text { hrs. }\end{array}$ & 41 \\
\hline & $\begin{array}{l}\text { C. rofingiensis } \\
\text { C. vulgaris }\end{array}$ & $\begin{array}{l}\text { Exopolysaccharide (EPS) of } C \text {. } \\
\text { zofingiensis and C. vulgaris }\end{array}$ & $\begin{array}{l}\text { HCT8 cells were exposed with EPS of } \\
\text { C. zofingiensis and C. vulgaris at } 0.15,0.3 \\
\text { and } 0.6 \mathrm{mg} / \mathrm{ml} \text { for } 24 \text { hrs. }\end{array}$ & 42 \\
\hline & C. pyrenoidosa & $\begin{array}{l}\text { Exopolysaccharide (EPS) of } C \text {. } \\
\text { pyrenoidosa }\end{array}$ & $\begin{array}{l}\text { HCT8 or HCT116 cells were exposed } \\
\text { with EPS of C. pyrenoidosa at } 0.15,0.3 \text {, } \\
\text { and } 0.6 \mathrm{mg} / \mathrm{ml} \text { for } 24 \text { hrs. }\end{array}$ & 43 \\
\hline
\end{tabular}




\begin{tabular}{|c|c|c|c|c|}
\hline \multirow[t]{3}{*}{ Lung } & C. vulgaris $\mathrm{C}-\mathrm{C}$ & $\begin{array}{l}\text { Supercritical carbon dioxide extract } \\
\text { of C. vulgaris }\end{array}$ & $\begin{array}{l}\text { Supercritical carbon dioxide extract of } \\
\text { C. vulgaris at } 200,100 \text {, and } 20 \mathrm{~g} / \mathrm{ml} \text { was } \\
\text { exposed to non-small cell lung cancer } \\
\text { (NSCLC), H1299, A549, and H1437 } \\
\text { cells for } 24 \text { hrs. }\end{array}$ & $\overline{44}$ \\
\hline & C. sorokiniana & $\begin{array}{l}\text { C. sorokiniana (provided by } \\
\text { International Cryptomonadales } \\
\text { Biotechnology, Taiwan) water } \\
\text { extract }\end{array}$ & $\begin{array}{l}\text { C. sorokiniana water extract at } 0-1000 \\
\text { ng/ml was treated to NSCLC cell line, } \\
\text { A } 549 \text {, and CL1- } 5 \text { for } 24 \text { hrs. }\end{array}$ & 45 \\
\hline & & $\begin{array}{l}\text { C. sorokiniana was dissolved in } \\
\text { double distilled water }\end{array}$ & $\begin{array}{l}\text { C. sorokiniana oral intake at } 50 \mathrm{mg} / \mathrm{kg} \\
\text { body weight of mice bearing tumor } \\
\text { (CL1-5 cells injected subcutaneously in } \\
\text { the right flank of mice). Oral intake was } \\
\text { carried out for } 11 \text { days. }\end{array}$ & \\
\hline Lymphoma & C. sorokiniana & C. sorokiniana methanol extract & $\begin{array}{l}\text { C. sorokiniana methanol extract at } 7.8 \text {, } \\
15.6,31.2,62.5,125,250 \text { and } 500 \mu \mathrm{g} / \mathrm{ml} \\
\text { was exposed to murine } \mathrm{L} 5178 \mathrm{Y}-\mathrm{R} \\
\text { lymphoma cell line and normal } \\
\text { lymphocyte cells for } 24 \mathrm{hrs} \text {. }\end{array}$ & 46 \\
\hline Cervix & C. pyrenoidosa & $\begin{array}{l}\text { Organic extract (dichloromethane/ } \\
\text { methanol; 2:1) of } C \text {. pyrenoidosa } \\
(\mathrm{CP})\end{array}$ & $\begin{array}{l}\text { Pre-coated coverslips containing } \\
\text { vascular } \\
\text { endothelial growth factor (VEGF) and } \\
\mathrm{CP} \text { extracts at } 25,50 \text {, and } 100 \mu \mathrm{g} \text { were } \\
\text { placed over the } \\
\text { developing chorionic allantoic } \\
\text { membrane of fertilized chicken eggs for } \\
12 \text { days. } \\
\mathrm{CP} \text { extract at } 7.8,15.6,31.2,62.5,125 \text {, } \\
250 \text { and } 500 \mu \mathrm{g} / \mathrm{ml} \text { was exposed to } \\
\text { HeLa cells for } 24 \mathrm{hrs} \text {. }\end{array}$ & 47 \\
\hline Stomach & C. vulgaris & $\begin{array}{l}\text { Peptide fraction isolated from } \\
\text { pepsin hydrolysate of C. vulgaris } \\
\text { protein waste }\end{array}$ & $\begin{array}{l}\text { Peptide fraction of } C \text {. vulgaris was } \\
\text { exposed to stomach cancer cells AGS, } \\
\text { human colon adenocarcinoma cells } \\
\text { C2BBel, human hepatoblastoma cell } \\
\text { lines Hep G2, and human cervical } \\
\text { epithelioid carcinoma cells, Hela for } 24 \\
\text { hrs. }\end{array}$ & 48 \\
\hline Prostate & C. marina & $\begin{array}{l}\text { - lycopene } \\
\text { (cis and trans 60:40) isolated from } \\
\text { C. marina (CL) } \\
\text { - Tomato lycopene (CL) }\end{array}$ & $\begin{array}{l}\text { PC-3 and DU-145 cancer cells } \\
\text { were treated with AL and TL ( } 20 \text { and } 50 \\
\mu \mathrm{M} \text {, respectively) for } 24 \text { hrs }\end{array}$ & 49 \\
\hline
\end{tabular}

out Sulaiman et al.33 that supplementation of C. Chlorella vulgaris at $300 \mathrm{mg} / \mathrm{kg} / \mathrm{day}$ in a rat diet not only vulgaris diet reduced the number of preneoplastic liver allow preneoplastic tumor in the liver to shrink to $83 \%$ nodules formed in ethionine-induced liver of the initial tumors but also suppress tumor carcinogenesis rats. They also found that antioxidative proliferation. ${ }^{35}$ Several explanations were reported with enzymes, superoxide dismutase (SOD), and catalase that regards to the tumours shrinkage and suppression in the were observed to be high in ethionine-induced liver liver. The first plausible explanation is that Chlorella carcinogenesis rats were low when C. vulgaris diet was vulgaris aqueous extract induces apoptosis by lowering fed to these rats. This confirmed the C. vulgaris effect the expression of the anti-apoptotic protein, Bcl-2 against liver cancer as SOD and catalase that are which is associated with hepatocyte proliferation but responsible for eliminating excessive free radicals is low increases the expression of pro-apoptotic protein, when given $C$. vulgaris diet to the liver cancer-induced caspase 8 that correlates with increased apoptosis. ${ }^{36}$ rats. Sulaiman et al. ${ }^{33}$ suggested that the $C$. vulgaris effect More recent study reported the ability of Chlorella vulgaris against liver cancer maybe through the reduction of to downregulate the expression of liver tumor markers lipid peroxidation as they found that the increase MDA in liver tissue such as M2-pyruvate kinase (M2-PK), level in liver cancer-induced rats was reduced when fed alpha-fetoprotein (AFP) and a specific antigen for oval with C. vulgaris diet. Increase lipid peroxidation in the cells (OV-6) as well as transforming growth factor- $\beta$ body has repeatedly shown to lead to the formation of (TGF- $\beta$ ) in serum. ${ }^{37}$ cancer. ${ }^{34}$

In vitro studies showed hot water extract of Chlorella A group of researchers demonstrated that high doses of vulgaris possessed an antiproliferative effect against 
HepG2 liver cancer cells, with an $\mathrm{IC}_{50}$ of $1.6 \mathrm{mg} / \mathrm{mL} .38$ It is important to note that high $\mathrm{IC}_{50}$ is acceptable as Chlorella vulgaris is classified as food and not a drug. Further tests on HepG2 liver cancer cells showed Chlorella vulgaris aqueous extract at $2 \mathrm{mg} / \mathrm{mL}$ caused $70 \%$ apoptosis of HepG2 cells compared with normal liver cells, WRL-68 which showed 15\% apoptosis when treated at the same dose. A higher apoptotic percentage of HepG2 liver cancer cells can be elucidated by the inhibition of DNA synthesis which eventually caused DNA damage. 38 Of the many reasons, the antioxidant properties of Chlorella vulgaris have been a key feature that induces apoptosis in activated hepatic stellate cells (HSC) and thereby ameliorate liver fibrosis. ${ }^{39}$ Detailed mechanism of apoptosis in HepG2 liver cancer cells has been further described by Yusof et $a^{\beta 6}$ that a series of signaling cascades are involved in the apoptotic pathway which includes increased expression of pro-apoptotic proteins such as p53, Bax, and caspase-3 and decreased expression of anti-apoptotic protein Bcl-2. Besides inhibiting the proliferation of cancer cells, Chlorella also can prevent the tumor from metastasizing. During tumor development, basement membrane disruption is an essential step for tumor invasion and metastasizes. This condition occurs due to the highly expressed extracellular matrix metalloproteases MMP-2 and MMP-

9. Protein extract of Chlorella minutissima was observed to suppress the overexpression of metalloproteases MMP-

2 and MMP-9 in HepG2 cells. ${ }^{29}$ Considering the potential of Chlorella in reducing further damage caused by free radicals, suppressing tumor proliferation, and preventing cancer cells from metastasizing, it can be suggested that Chlorella has high potential in cancer remedies.

\section{Colorectal Cancer}

Microalgal carotenoids have been used in the treatment of colorectal cancer combined with the chemotherapeutic agent 5-fluorouracil to facilitate complete remission. ${ }^{24}$ Previous study showed carotenoids extracted from Chlorella ellipsoidea and C. vulgaris were cytotoxic to human colon cancer cells, HCT116.40 Carotenoids from both species were also found to exert apoptosis-inducing effect to the colon cancer cells with C. ellipsoidea carotenoids showing 2.5 times stronger effect than $C$. vulgaris carotenoids.
Carotenoids responsible for this activity might be violaxanthin as HPLC analysis revealed that violaxanthin is the main carotenoid found in $C$. ellipsoidea.

Chlorella protothecoides oil extract encapsulated within polymer micro-particles also showed a cytotoxic effect on similar colon cancer cell line, HCT116.41 Having polymer encapsulating the microalgal oil does not only protect the algal bioactive compounds but it also allows expression of comparable cytotoxicity effect that stimulated by non-encapsulated microalgal oil. Other than microalgae intracellular compounds, many studies also focused on the production and anti-cancer properties of microalgal exopolysaccharide (EPS). The EPS extracted from C.pyrenoidosa, C. zofingiensis, and $C$. vulgaris at a concentration of $0.6 \mathrm{mg} / \mathrm{mL}$ showed significant inhibitory effects at 35.9, 28.3, and 18.0\%, respectively against human colon cancer cell lines HCT8. ${ }^{42.43}$ The inhibition activity against tested colon cancer cell lines indicates that EPS from Chlorella sp. may be effective agents for anti-cancer therapeutics.

\section{Others}

Other than significant effects of Chlorella on breast, liver, and colon cancers; multiple studies had been conducted to study the effect of Chlorella on other types of cancers. Several studies had been carried out to investigate the effects of Chlorella sp. on non-small cell lung cancer (NSCLC) which is the most common type of lung cancer that usually starts from the outer part of the lungs. It has been shown that $C$. vulgaris extract obtained using supercritical carbon dioxide extraction (SC-CO $)_{2}$ method inhibited NSCLC cell lines, H1299, A549, and H1437 cells in a dose-dependent manner. ${ }^{44}$ In the same study, they demonstrated the extract significantly decreased the migration of all tumor cells, suggesting that $C$. vulgaris extract may inhibit metastasis of lung cancer. The exact bioactive compounds responsible for these activities, however, were not identified in this study nevertheless they found that the extract has a high content in polyphenolic and flavonoid compounds. Chlorella sorokiniana was also found to inhibit the growth of NSCLC cell line, A549 as well as CL1-5 in a different study. ${ }^{45}$ In vivo study carried out by Lin et al ${ }^{45}$ showed tumor growth of CL1-5 cells injected 
subcutaneously in the right flank of mice was markedly inhibited after oral intake of $C$. sorokiniana. They showed that the effect of C. sorokiniana against NSCLC cells is through induction of mitochondrial-mediated apoptosis by downregulation of Bcl-2, XIAP, and survivin.

In recent study, C. sorokiniana methanol extract was tested against lymphoma cells, L5178Y-R, and was demonstrated to cause $61 \%$ tumor cell toxicity at 500 $\mathrm{mg} / \mathrm{mL} .{ }^{46}$ For this cytotoxic effect, C. sorokiniana causes apoptosis towards the lymphoma cells however it was not through the caspase- 3 activity. Chlorella also showed a negative effect on cervix cancer cells when organic extract (dichloromethane/methanol; 2:1) of Chlorella pyrenoidosa was found to inhibit the growth of HeLa cells at $\mathrm{IC}_{50}$ of $570 \mu \mathrm{g} / \mathrm{ml} .{ }^{47}$ As C. pyrenoidosa was also shown to be antiangiogenic in the same study ${ }^{47}$ (Figure 2), preventing the growth of new blood vessels may indirectly contribute to the fight against cervix cancer and maybe all types of cancer.

A study on identifying the substance that is responsible for the anticancer effect of $C$. vulgaris against adenocarcinoma stomach cancer cells, AGS demonstrated that $C$. vulgaris peptide fraction with low molecular weight had strong dose-dependent cytotoxic activity and stimulated cell cycle arrest at post-G1 in AGS cells. ${ }^{48}$ The peptide fraction possesses cell-specific effect as no significant inhibitive effect was observed against human colon adenocarcinoma cells C2BBel, human hepatoblastoma cell lines Hep G2, and human cervical epithelioid carcinoma cells, Hela. Among the peptides in the fraction, a short peptide with an amino acid sequence, VECYGPNRPQF showed effective antiproliferative, antioxidant, and anti-inflammatory activities. Comparison investigation on lycopene extracted from Chlorella marina and tomato showed that algal lycopene $(\mathrm{AL})$ inhibited the growth and colony formation of prostate cancer cells, PC-3 and DU-145 more effectively than tomatal lycopene (TL). ${ }^{49} \mathrm{AL}$ also induced apoptosis and arrested the cell cycle at the $\mathrm{G}_{0} /$ $\mathrm{G}_{1}$ phase at a higher level than TL. The authors suggested that AL showed a higher effect than TL may be due to the presence of a mixture of cis- and translycopene in AL while only trans-lycopene was found in TL. It has been demonstrated that cis-lycopene is easily absorbed and possess higher antioxidant activity compared to all-trans lycopene. ${ }^{50}$

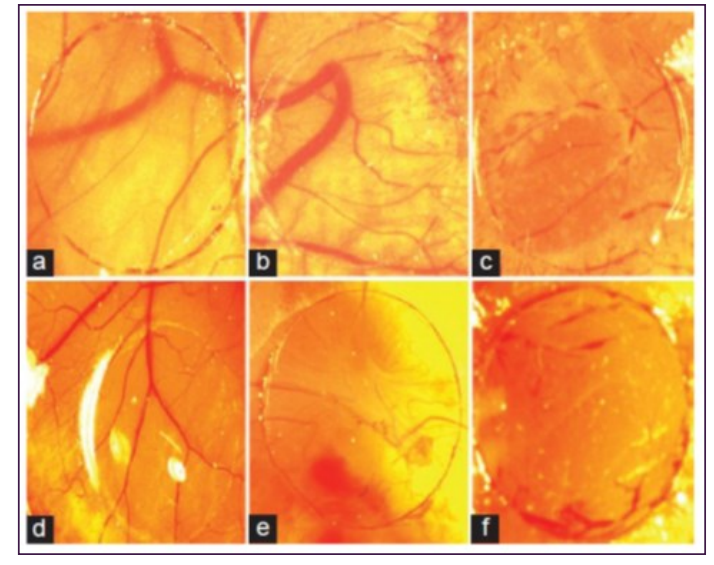

Figure 2: Indicated the chorioallantoic membrane (CAM) of a 12 day old chick embryo incubated for 4 days with a coverslip treated with or without treatment. (a) Normal, without treatment; (b) Treated with vascular endothelial growth factor, VEGF (50 ng); (c) Treated with VEGF (50 ng) + thalidomide $(10 \mu \mathrm{g})$; (d-f) Treated with VEGF (50 ng) + C. pyrenoidosa, CP at the concentrations of 25, 50, and $100 \mu \mathrm{g}$, respectively. CAM treated with VEGF showed profuse growth of blood vessels while treatment with VEGF + CP extracts demonstrated decreased blood vessel density in a dosedependent manner. ${ }^{47}$

\section{CONCLUSION}

Chlorella is photosynthetic eukaryotic microorganisms that possess diverse effects on health benefits in both humans and animals. Owing to its intracellular and extracellular compounds, Chlorella has strong potential in cancer treatments and reduces the side effects of conventional anticancer agents. To date, Chlorella either in powder, crude extract form, or specific compounds demonstrated potent effects against various types of cancer. Its consistent effects on cell cycle arrest, apoptosis of cancer cells, downregulating components involve in migration and proliferation of cells as well inhibiting angiogenesis play important roles in inhibiting cancer growth.

Other than that, Chlorella also stimulates the production and maturation of granulocytes and macrophages in vivo that could lead to the anti-cancer effect. As of now, Chlorella is widely used as supplementary after conventional cancer treatment as well as for general health purposes. Although Chlorella's effects against cancer are not as potent as conventional chemotherapy agents, daily consumption of Chlorella will at least halted the growth of potential cancer cells after cancer patients stop receiving their treatments. 


\section{REFERENCES}

1. World Health Organization. Cancer [online]. Available at: https://www.who.int/news-room/ fact-sheets/detail/cancer. Accessed March 21, 2020.

2. International Agency for Research on Cancer. Latest global cancer data: cancer burden rises to 18.1 million new cases and 9.6 million cancer deaths in 2018. International Agency for Research on Cancer: Lyon, France, 2018.

3. Arruebo M, Vilaboa N, Sáez-Gutierrez B, et al. Assessment of the evolution of cancer treatment therapies. Cancers (Basel) 2011; 3(3):3279-330.

4. Hur W and Yoon SK. Molecular pathogenesis of radiation-induced cell toxicity in stem cells. Int $\mathrm{J}$ Mol Sci 2017; 18:2749-64.

5. Mughal TI, Schrieber A. Principal long-term adverse effects of imatinib in patients with chronic myeloid leukemia in chronic phase. Biologics 2010; 4:315-23.

6. Shanab SMM, Mostafa SSM, Shalaby EA, Mahmoud GI. Aqueous extracts of microalgae exhibit antioxidant and anticancer activities. Asian Pac J Trop Bmed 2012; 2(8):608-15.

7. Konishi F, Mitsuyama M, Okuda M, et al. Protective effect of an acidic glycoprotein obtained from culture of chlorella vulgaris against myelosuppression by 5 -fluorouracil. Cancer Immunology Immunotherapy 1996; 42 (5):268-74.

8. Azaman SNA, Nagao N, Yusoff FM, Tan SW, Yeap SK. A comparison of the morphological and biochemical characteristics of Chlorella sorokiniana and Chlorella zofingiensis cultured under photoautotrophic and mixotrophic conditions. PeerJ 2017; 5:e3473.

9. Berliner MD. Proteins in Chlorella vulgaris. Microbios 1986; 46:199-203.

10. Becker EW. Micro-algae as a source of protein. Biotechnol Adv. 2007; 25:207-10.

11. Guschina IA and Harwood JL. Algal lipids and their metabolism. In: Borowitzka MA, Moheimani NR, eds. Algae for Biofuels and Energy. Dordrecht, Netherlands: Springer, 2013.

12. Julius ML. Carbohydrate Diversity in Microalgae: A Phylogenetically Arranged
Presentation. In: Levine IA, Fleurence J, eds. Microalgae in Health and Disease Prevention. London, UK: Academic Press, 2018: 133-142.

13. Takeda H. Sugar composition of the cell wall and the taxonomy of Chlorella (Chlorophyceae). $J$ Phycology 1991; 27:224-32.

14. Fox JM, Zimba PV. Minerals and Trace Elements in Microalgae. In: Levine IA, Fleurence J, eds. Microalgae in Health and Disease Prevention. London, UK: Academic Press, 2018: 177-93.

15. Safi C, Zebib B, Merah O, Pontalier PY, VacaGarcia C. Morphology, composition, production, processing and applications of Chlorella vulgaris: A review. Renew Sust Ener Rev 2014; 35:265-78

16. Liu J, Hu Q. Chlorella: Industrial production of cell mass and chemicals. In: Richmond A, Hu Q, eds. Handbook of Microalgal Culture: Applied Phycology and Biotechnology. Oxford, UK: Wiley, 2013: 327-338.

17. Cordero BF, Obraztsova I, Couso I, et al. Enhancement of lutein production in Chlorella sorokiniana (Chorophyta) by improvement of culture conditions and random mutagenesis. Marine Drugs 2011; 9:1607-24.

18. Liu J, Huang J, Jiang Y, Chen F. Molasses-based growth and production of oil and astaxanthin by Chlorella zofingiensis. Bioresource Tech 2012; 107:393-98.

19. Suárez E R, Kralovec J A, Noseda M D, et al. Isolation, characterization and structural determination of a unique type of arabinogalactan from an immunostimulatory extract of Chlorella pyrenoidosa. Carbohydrate Res 2005; 340:1489-98.

20. Kim S, Kim J, Lim Y, et al. A dietary cholesterol challenge study to assess Chlorella supplementation in maintaining healthy lipid levels in adults: a double-blinded, randomized, placebo-controlled study. Nutr J 2016; $15: 54$.

21. Merchant RE, Andre CA, Sica D A. Nutritional supplementation with Chlorella pyrenoidosa for mild to moderate hypertension. J Med Food 2002; 5:141-52.

22. Merchant RE, Andre CA. A review of recent clinical trials of the nutritional supplement Chlorella pyrenoidosa in the treatment of 
fibromyalgia, hypertension, and ulcerative colitis. Alt Ther Health Med 2001; 7:79.

23. Nazih H, Bard JM. (2018). Microalgae in Human Health: Interest as a Functional Food. In: Levine IA, Fleurence J, eds. Microalgae in Health and Disease Prevention. London, UK: Academic Press, 2018: 211-220.

24. Abd El-Hack ME, Abdelnour S, Alagawany M, et al. Microalgae in modern cancer therapy: Current knowledge. Biomed Pharmaco 2019; 111:42-50.

25. Miyazawa Y, Murayama T, Ooya N, et al. Immunomodulation by a unicellular green algae (Chlorella pyrenoidosa) in tumor-bearing mice. J Ethnopharmacology 1988; 24(2-3):135-46.

26. Justo GZ, Silva MR, Queiroz ML. Effects of the green algae Chlorella vulgaris on the response of the host hematopoietic system to intraperitoneal ehrlich ascites tumor transplantation in mice. Immunopharm and Immunotox 2001; 23(1):11932.

27. Ramos AL, Torello CO, Queiroz ML. Chlorella vulgaris modulates immunomyelopoietic activity and enhances the resistance of tumor-bearing mice. Nutr Cancer 2010; 6(8):1170-80.

28. Kubatka P, Kapinova A, Kruzliak P, et al. Antineoplastic effects of Chlorella pyrenoidosa in the breast cancer model. Nutrition 2015; 31 (4):560-69.

29. Kunte M, Desai K. The protein extract of Chlorella minutissima inhibits the expression of MMP-1, MMP-2 and MMP-9 in cancer cells through upregulation of TIMP-3 and down regulation of c-Jun. Cell J 2018; 20(2):211-19.

30. Wang QM, Lv L, Tang Y, Zhang L, Wang LF. MMP-1 is overexpressed in triple-negative breast cancer tissues and the knockdown of MMP-1 expression inhibits tumor cell malignant behaviors in vitro. Oncology let 2019; 17(2):173240.

31. Zhang Y, Pu X, Shi M, et al. Critical role of c-Jun overexpression in liver metastasis of human breast cancer xenograft model. BMC Cancer 2007; 7(1):1-8.

32. Lee C, Lim K, Kim SS, et al. Chlorella-gold nanorods hydrogels generating photosynthesisderived oxygen and mild heat for the treatment of hypoxic breast cancer. Journal of Controlled Disease 2019; 294:77-90.

33. Sulaiman S, Shamaan NA, Ngah WZW, Yusof YAM. Chemopreventive effect of Chlorella vulgaris in choline deficient diet and ethionine induced liver carcinogenesis in rats. Int J Cancer Res 2006; 2(3):234-41.

34. Van der Paal J, Neyts EC, Verlackt CC, Bogaerts A. Effect of lipid peroxidation on membrane permeability of cancer and normal cells subjected to oxidative stress. Chem Sc 2016; 7(1):489-98.

35. Mukti NA, Sulaiman S, Saad SM, Basari H. Chlorella vulgaris menunjukkan kesan antioksidan dan antitumor terhadap kanser hepar dalam kajian in vivo dan in vitro. Sains Malaysiana 2009; 38(5):772-84.

36. Yusof YAM, Saad SM, Makpol S, Shamaan NA, Ngah WZW. Hot water extract of Chlorella vulgaris induced DNA damage and apoptosis. Clinics 2010; 65(12):1371-77.

37. Ariffin KT, Sulaiman S, Saad SM, et al. Elevation of tumour markers TGF- $\beta$, M 2-PK, OV-6 and AFP in hepatocellular carcinoma (HCC)-induced rats and their suppression by microalgae Chlorella vulgaris. BMC cancer 2017; 17(1):879.

38. Saad SM, Yusof YAM, Ngah WZW. Comparison between locally produced Chlorella vulgaris and Chlorella vulgaris from Japan on proliferation and apoptosis of liver cancer cell line HepG2. Malaysian J Bchem Mol Biol 2006; 13:32-6.

39. Wu LC, Ho JAA, Shieh MC, Lu IW. Antioxidant and antiproliferative activities of spirulina and chlorella water extracts. J Agri Food Chem 2005; 53(10):4207-12.

40. Cha KH, Koo SY, Lee DU. Antiproliferative effects of carotenoids extracted from Chlorella ellipsoidea and Chlorella vulgaris on human colon cancer cells. J Agric and Food Chem 2008; 56:10521-26.

41. Karakas CY, Tekarslan Sahin H, Inan B, Ozcimen D, Erginer YO. In vitro cytotoxic activity of microalgal extracts loaded nano-micro particles produced via electrospraying and microemulsion methods. Biotech Prog 2019; 35 (6): e2876.

42. Zhang J, Liu L, Chen F. Production and 
characterization of exopolysaccharides from

Chlorella zofingiensis and Chlorella vulgaris with anti-colorectal cancer activity. Int J Biol

Macromol 2019a; 134:976-83.

43. Zhang J, Liu L, Ren Y, Chen F. Characterization of exopolysaccharides produced by microalgae with antitumor activity on human colon cancer cells. Int J Biol Macromol 2019b; 128:761-67.

44. Wang HM, Pan JL, Oliver Chen CY, et al. Identification of anti-lung cancer extract from Chlorella vulgaris $\mathrm{C}-\mathrm{C}$ by antioxidant property using supercritical carbon dioxide extraction. Process Biochem 2010; 45 (12):1865-72.

45. Lin PY, Tsai CT, Chuang WL, et al. Cblorella sorokiniana induces mitochondrial-mediated apoptosis in human non-small cell lung cancer cells and inhibits xenograft tumor growth in vivo. BMC Comp Alt Med 2017; 17(1):88.

46. Reyna-Martinez R, Gomez-Flores R, LópezChuken U, et al. Antitumor activity of Chlorella sorokiniana and Scenedesmus sp. microalgae native of Nuevo León State, México. PeerJ 2018; 6:e4358.

47. Kyadari M, Fatma T, Azad R, Velpandian T.

Evaluation of antiangiogenic and antiproliferative potential of the organis extract of green algae Chlorella pyrenoidosa. Indian J Pharmaco 2013; 45(6):569.

48. Sheih IC, Fang TJ, Wu TK, Lin PH. Anticancer and antioxidant activities of the peptide fraction from algae protein waste. J Agric Food Chem 2010; 58(2):1202-7.

49. Renju GL, Muraleedhara Kurup G, Bandugula VR. Effect of lycopene isolated from Chlorella marina on proliferation and apoptosis in human prostate cancer cell line PC-3. Tumour Biol 2014; 35(11):10747-58.

50. Tanambell H, Quek SY, Bishop K S. Screening of in vitro health benefits of tangerine tomatoes. Antioxidants 2019; pii: E230. 